\title{
PENGARUH PEMBERIAN BEBERAPA JENIS BOKASHI TERHADAP PERTUMBUHAN DAN HASIL TANAMAN TERUNG (Solanum melongena $L$ )
}

\author{
Firdo Ramadan,_Budi Prastia \\ Program Studi Agroteknologi Fakultas Pertanian \\ Universitas Muara Bungo \\ Artikel Diterima 18 November 2020, disetujui 10 Januari 2021 \\ ABSTRAK
}

Penelitian ini dilaksanakan di lahan penduduk Kelurahan Sungai Pinang Kecamatan Bungo Dani Kabupaten Bungo dilaksanakan selama 4 bulan dari tanggal 01 Desember 2016 sampai dengan 30 Maret 2017. Tujuan penelitian ini adalah untuk mengetahui Pengaruh Pemberian Beberapa Jenis Bokashi Terhadap Pertumbuhan dan Hasil Tanaman Terung (Solanum melongena L). Rancangan yang digunakan dalam penelitian ini adalah Rancangan Acak Lengkap (RAL) dengan 5 perlakuan dan 4 ulangan, adapun perlakuan B0 (tanpa perlakuan), B1 Pemberian pupuk bokasi alang-alan, B2 Bokashi enceng gondok, B3, Bokashi Serbuk Gergaji dan B4 Bokashi Pupuk Kandang Sapi. Hasil pengamatan dianalisis dengan menggunakan Analisis Ragam (Anova), apabila berpengaruh nyata maka dilanjutkan dengan uji Duncan New Multiple Range Test (DNMRT) pada taraf $5 \%$. Parameter yang diamati adalah tinggi tanaman (cm), jumlah daun per tanaman (helai), jumlah cabang primer dan rataan jumlah buah per tanaman. Dari hasil penelitian menunjukan bahwa pemberian berbagai jenis pupuk bokashi berpengaruh nyata terhadap tinggi tanaman (cm dan jumlah buah per tanaman, akan )i tidak berpengaruh nyata terhadap jumlah daun per tanaman (helai) dan jumlah cabang priı. . (buah). Perlakuan B1 merupakan perlakuan terbaik terhadap hasil tanaman terung.

Kata Kunci : Pupuk Organik Bokashi, Pertumbuhandan Hasil Terung

\section{PENDAHULUAN}

Terung (Solanum melongena L.) merupakan tanaman sayur-sayuran yang termasuk famili Solanaceae. Buah terung banyak disenangi orang baik sebagai lalapan segar maupun diolah menjadi berbagai jenis masakan.

Menurut Marpaung, (2010) bahwa setiap $100 \mathrm{~g}$ bahan mentah terung mengandung 26 kalori, $1 \mathrm{~g}$ protein, $0,2 \mathrm{~g}$ hidrat arang, 25 vitamin $\mathrm{A}, 0,04 \mathrm{~g}$ vitamin $\mathrm{B}$ dan $5 \mathrm{~g}$ vitamin $\mathrm{C}$. Di tahun 2014 produksi terung Provinsi jambi mencapai 82,08 kw/h sementara pada tahun 2015 menjadi 69,56 $\mathrm{kw} / \mathrm{ha}$, atau terjadi penurunan sekitar 15,25 $\%$ (BPS Jambi 2015). Sementara permintaan terhadap terung di Provinsi Jambi terus meningkat sejalan dengan pertambahan penduduk yang diikuti dengan meningkatnya kesadaran akan manfaat sayur-sayuran dalam memenuhi gizi keluarga, sehingga produksi tanaman terung perlu terus ditingkatkan.

Untuk mencapai peningkatan tersebut upaya yang dapat ditempuh di antaranya adalah pemilihan bibit unggul, pengaturan pola tanam, pengendalian hama dan penyakit dan pemupukan. Pemupukan merupakan salah satu faktor yang penting untuk dianjur-kan, karena pemupukan berarti dapat meningkatkan produktivitas serta kesuburan lahan (Widodo, 2013). Pupuk organik adalah bahan yang ditambahkan ke dalam tanah untuk meningkatkan pertumbuhan dan hasil tanaman. Beberapa jenis pupuk organik yang sering digunakan dalam pertanian 
antara lain adalah pupuk kandang, pupuk hijau dan bokashi.

Pupuk organik memiliki banyak kelebihan dibandingkan dengan penggunaan pupuk anorganik.Pupuk organik selain menambah hara yang lengkap pada tanaman dapat pula memperbaiki sifat fisik, kimia dan biologi tanah, dengan memperbaiki struktur tanah, meningkatkan kapasitas tukar kation (KTK), menambah kemampuan tanah menahan air serta meningkatkan aktivitas mikroorganisme tanah.Pada beberapa tanah masam pupuk organik dapat meningkatkan $\mathrm{pH}$ tanah (menetralkan $\mathrm{Al}$ dengan membentuk kompleks Al organik).

Selain itu, pupuk organik tidak menimbulkan polusi bagi tanah khususnya dan lingkungan umumnya.Salah satu jenis pupuk organik yang dapat diberikan adalah dengan memanfaatkan sisa-sisa tanaman atau limbah pertanian, di antaranya adalah eceng gondok, alang-alang, serbuk gergaji dan kotoran sapi.

Rahmad.(2000) menyatakan bahwa kecepatan degradasi bokashi bahan organik tergantung pada aktivitas mikroorganisme yang terkandung di dalamnya.Oleh karena itu untuk mempercepat degradasi bokashi bahan organik digunakan EM4 (Effective Microorganism 4).

Teknologi EM4 merupakan salah satu konsep pemanfaatan mikroorganisme tanah bersifat menguntungkan untuk meningkatkan kesuburan tanah.Penerapan teknologi EM4 dapat dilakukan dengan memfermentasikan berbagai bahan organik, seperti enceng gondok, alang-alang, pupuk kandang, dan serbuk gergaji dengan larutan EM4 (Soverda $d k k$ 2008).

Hasil penelitian Soverda, dkk (2008) menyatakan bahwa pemberian berbagai jenisbokashi berbahan dasar kotoran sapi, enceng gondok, serbuk gergaji dan alangalang berpengaruh nyata terhadap pertumbuhan dan hasil tanaman terung.

METODOLOGI PENELITIAN
Penelitian ini dilaksanakan di lahan milik penduduk Kelurahan Sungai Pinang Kecamatan Bungo Dani Kabupaten Bungo. Lokasi terletak pada ketinggian $101 \mathrm{~m} \mathrm{dpl,}$ pada jenis tanah ultisol dengan $\mathrm{pH}$ 4,5 (Monografi Kelurahan Sungai Pinang, 2016).

Penelitian ini dilaksanakan selama 4 bulan yang akan dimulai pada tanggal 01 Desember 2016 sampai dengan 30 Maret 2016. Bahan yang digunakan dalam penelitian ini adalah benih terung varietas ungu,tanah bagian topsoil, polybag ukuran $30 \mathrm{~cm}$ X $40 \mathrm{~cm}$, kotoran sapi, eceng gondok, serbuk gergaji, alang-alang, air bersih dan EM-4. Alat yang digunakan dalam penelitian ini adalah cangkul, ayakan, kayu, bambu, timbangan, penggaris/meteran, jaring dan alat tulis.

Penelitian ini menggunakan Rancangan Acak Lengkap (RAL) dengan 5 perlakuan dan 4 ulangan, dimana perlakuanya adalah sebagai berikut:

B0 = Tanpa Perlakuan

$\mathrm{B} 1=500 \mathrm{~g} /$ polybag Bokashi Alangalang

$\mathrm{B} 2=500 \mathrm{~g} /$ polybag Bokashi Eceng Gondok

B3 $=500 \mathrm{~g} /$ polibag bokashi serbuk Gergaji

B4 $=500 \mathrm{~g} /$ polibag Bokashi Pupuk Kandang Sapi

Masing-masing perlakuan diulang sebayak 4 kali, sehingga diprr 20 unit percobaan. Penetapan unit cobaan dilakukan secara acak. Jumlah tiap unit percobaan 3 bibit sehingga jumlah keseluruhan bibit $20 \times 3=60$ bibit dan keseluruannya dijadikan sampel.jarak antar unit perlakuan 30 X $30 \mathrm{~cm}$.

\section{Pelaksanaan Penlitian}

Tempat penelitian didatarkan dengan tujuan untuk meletakan media polybag. Tempat dibersihkan dari berbagai jenis gulma yang tumbuh setelah itu dipasang 
pagar jaring untuk menghindari gangguan hewan ternak. Persemaian dilakukan dimedia semai di atas tanah, dengan media semai campuran pasir dan tanah dan pupuk kandang dengan perbandingan 1.1.1 sebelum benih terung di semaikan dilakukan perendaman terlebih dahulu selama 1 malam dan di semai saat pagi hari lama persemaian berkisar 1 minggu. Pengambilan tanah dilakukan satu minggu sebelum tanam tanah yang diambil adalah lapisan atas (topsoil). Setiap perlakuan ada 3 polibag maka untuk 20 perlakuan berarti $20 \times 3$ polybag $=60$ polybag .Tanah yang dibutuhkan adalah 60 polibag X $4 \mathrm{~kg}=240 \mathrm{~kg}$ tanah topsoil ultisol. Persiapan pembuatan pupuk bokashi dilakukan 30 hari sebelum pengolahan lahaan, sehingga pada saat diberikan untuk persiapan perlakuan pupuk sudah siap digunakan.Pemberian perlakuan dengan cara mencampurkan pupuk bokashi dengan tanah topsoil secara merata pada setiap polybag di tanah $4 \mathrm{~kg}$ / polybag untuk setiap perlakuan. Pemberian perlakuan di sesuaikan dengan label kode yang dibuat.Penanaman dilakukan 1 minggu setelah media disiapkan dengan cara memindahkan bibit dari persemaian kedalam media polybag. Bibit yang diambil harus bibit yang sehat tumbuh seragam, setelah selesai dipindahkan maka bibit disiram agar media menjadi lembab dan tanah dipadatkan.

\section{Pemeliharaan tanaman}

Penyiraman dilakukan pagi antara pukul 08.00- 09.30 WIB,sedangkan sore hari dilakukan antara pukul 17- 17.30 WIB.jika umur tanaman masih berumur dibwah 20 hst penyiraman dilakukan secara hati-hati karena tanaman akan mudah roboh yaitu dengan cara menyemprot dengan gembor (alat penyiraman air).

Pembumbunan dilakukan pada saat 20 hst, dengan cara mengemburkan tanah disekitar perakaran tanaman. Pembumbunan dilakukan secara hati-hati agar tidak merusak perakaran tanaman.Pengendalian gulma dilakukan bersamaan dengan saat pembumbunan, selanjutnya pengendalian gulma dilakukan secara menual yaitu dengan cara mencabut seluruh gulma yang tumbuh di polibag dan membersihkan gulma yang hidup di sekitar dimana polibag diletakan Pengendalian hama dilakukan dengan mengunakan larutan pestisida jenis decis dengan dosis $3 \mathrm{cc} / 1$ air pada saat 45 hst.Pengendalian penyakit dilakukan sejak mulai perendaman benih dengan menggunakan larutan fumgisida jenis ditnane selama 8 jam dengan dosis $5 \mathrm{cc} / 1$ air. Selanjutnya pengendalian saat di lapangan dilakukan sesuai dengan jenis penyakit yang muncul pada tanaman .

\section{Parameter yang diamati :}

Pengamatan tinggi tanaman dilakukan dengan cara mengukur dengan menggunakan tali dari ajir sampi pada ujung tumbuh. Pengukuran dilakukan 6 kali mulai dari 14 hst,28 hst,58 hst. Pengamatan jumlah daun dilakukan satu kali yaitu pada saat 58 hst. Pengamatan jumlah daun dilakukan dengan cara menghitung seluruh jumlah daun yang tumbuh pada tanaman sampel dan rara-ratakan.Pengamatan cabang primer dilakukan satu kali yaitu pada saat panen buah pertama yaitu 90 hst, Pengamatan jumlah buah per tanaman dilakukan sejak panen pertama yaitu 90 hst, hingga panen ke 4 dengan interval panen satu minggu satu kali. Pengamtan dilakukan dengan cara menghitung seluruh buah yang dipanen. Hasil buah segar diperoleh dengan cara menimbang bobot buah segar hasilnya dikonversikan ke hektar dengan rumus sebagai berikut :

Luas $1 \mathrm{Ha}$ (A)

$\begin{array}{ll}\text { Hasil Per } & \text { X hasil per } \\ \text { Hektar }= & \text { petak (C) X } \\ & \text { Populasi (B) }\end{array}$

Keterangan: 
A : Luas $1 \mathrm{ha}\left(\mathrm{cm}^{2}\right)$

B : Luas Petak percobaan $\left(\mathrm{cm}^{2}\right)$

C : Hasil Panen Perpetak $(\mathrm{Kg})$

\section{Analisis Data}

Untuk melihat pengaruh parameter yang diamati, data hasil pengamatan dianalisis ragam, bila berpengaruh nyata maka dilanjutkan dengan uji DNMRT pada taraf 5 \% (Steel and Torrie, 1994).

\section{Tinggi Tanaman (cm)}

Hasil analisis ragam (Anova) menunjukkan bahwa pemberian beberapa macam bokashi berpengaruh nyata terhadap tinggi tanaman (lampiran 9a). Rataan tinggi tanaman dengan pemberian perlakuan beberapa macam bokashi dapat dilihat pada Tabel 1 .

\section{HASIL DAN PEMBAHASAN}

Tabel 1. Rataan Tinggi Tanaman (cm) dengan Perlakuan Pemberian Beberapa Macam Bokashi.

\begin{tabular}{|l|c|}
\hline \multicolumn{1}{|c|}{ Perlakuan } & Tinggi Tanaman (cm) \\
\hline B0 $=$ Tanpa Perlakuan & $33.79 \mathrm{~b}$ \\
B1 $=500 \mathrm{~g} /$ polybag Bokashi Alang-alang & $33.68 \mathrm{~b}$ \\
B2 $=500 \mathrm{~g}$ polybag Bokashi Eceng Gondok & $42.56 \mathrm{ab}$ \\
B3 $=500 \mathrm{~g} /$ polibag bokashi serbuk Gergaji & $41.94 \mathrm{ab}$ \\
B $\quad=500 \mathrm{~g} /$ polibag Bokashi Pupuk Kandang Sapi & $49.51 \mathrm{a}$ \\
\hline KK $=14,56 \%$ & \\
\hline
\end{tabular}

Keterangan :Angka-angka yang diikuti oleh huruf kecil yang berbeda pada kolom yang sama menunjukkan berbeda nyata menurut DNMRT pada taraf 5\%.

Tabel diatas menunjukkan perlakuan (B0) tidak berbeda dengan perlakuan (B1), (B2) dan (B3) akan tetapi berbeda dengan perlakuan (B4). Sedang perlakuan. (B2) tidak berbeda dari perlakuan (B3) dan (B4). Sehingga perlakuan terbaik adalah (B4) pada perlakuan 500g/polibag Bokashi Pupuk Kandang Sapi. Pengaruh pemberian berbagai jenis bokashi terhadap pertumbuhan tinggi tanaman yang dicapai menunjukkan bahwa pemberian bokashi kotoran sapi dapat memberikan pertumbuhan yang lebih baik dibandingkan dengan bokashi yang lainnya. Hal ini mungkin disebabkan oleh kandungan $\mathrm{N}$ pada bokashi kotoran sapi adalah yang tertinggi diantara bokashi yang lainnya.

Menurut Usman-Made (2010) menyatakan bahwa tersedianya Nitrogen yang cukup menyebabkan adanya keseimbangan rasio antara daun dan akar, maka pertumbuhan vegetatif berjalan normal dan sempurna sehingga dapat mempengaruhi pertumbuhan tanaman. Lebih lanjut dalam penelitian Sirajuddin dan Lasmini, (2010) dinyatakan bahwa pemberian pupuk Nitrogen pada tanaman terung merupakan hal yang sangat penting karena Nitrogen mempunyai efek nyata pada pertumbuhan tanaman yang dapat merangsang pertumbuhan akar, batang daun dan pertambahan tinggi tanaman.

Menurut Sholeh dkk, (1997) dalam Djunaedy (2009), menyatakan bahwa penambahan bahan organik (bokashi) ke dalam tanah dapat meningkatkan kandungan bahan organik dan unsur hara tanah. Hal ini karena semakin banyak dosis pupuk bokashi yang diberikan, maka $\mathrm{N}$ yang terkandung di dalam pupuk bokashi juga semakin banyak yang diterima oleh tanah. Unsur $\mathrm{N}$ merupakan unsur hara yang sangat penting 
karena merupakan unsur yang paling banyak dibutuhkan untuk pertumbuhan tanaman. Nitrogen berfungsi sebagai penyusun asamasam amino, protein komponen pigmen klorofil yang penting dalam proses fotosintesis. Sebaliknya jika kekurangan N menyebabkan pertumbuhan dan perkembangan tanaman terganggu dan hasil menurun yang disebabkan oleh terganggunya pembentukan klorofil yang sangat penting untuk proses fotosintesis.

Secara biologi pupuk bokashi dapat meningkatkan aktivitas mikroorganisme tanah. Mikroorganisme yang menguntungkan dan senyawa organik

Tabel 2. Rataan Jumlah Daun dengan Perlakuan Berbagai Jenis Pupuk Bokashi

\begin{tabular}{|l|c|}
\hline \multicolumn{1}{|c|}{ Perlakuan } & $\begin{array}{c}\text { Jumlah Daun } \\
\text { (helai) }\end{array}$ \\
\hline B0 $\quad=$ Tanpa Perlakuan & 8.83 \\
B1 $=500 \mathrm{~g} /$ polybag Bokashi Alang-alang & 11.41 \\
B2 $=500$ g/polybag Bokashi Eceng Gondok & 11.33 \\
B3 $=500 \mathrm{~g} /$ polibag bokashi serbuk Gergaji & 10.57 \\
B4 $=500 \mathrm{~g} /$ polibag Bokashi Pupuk Kandang Sapi & 11.33 \\
\hline KK $=14,49 \%$ & \\
\hline
\end{tabular}

Keterangan : Perlakuan tidak berpengaruh nyata terhadap rataan jumlah daun $(\mathrm{P}>0,05)$.

Dari Tabel diatas dapat dijelaskan bahwa perlakuan pemberian berbagai jenis pupuk bokashi tidak berpengaruh nyata terhadap jumlah daun. Jumlah daun tidak menunjukkan perbedaan nyata antar perlakuan, ditengarai karena jumlah daun banyak dipengaruhi kondisi factor media tanam yang keras. Media jenis tanah ultisol yang masam dimana kahat unsur hara, media tersebut terlalu padat sehingga tidak cukup tersedia oksigen untuk keperluan respirasi akar tanaman.

Sarief (2009) menyatakan bahwa tanah yang padat dapat berpengaruh langsung terhadap perkembangan akar, akibatnya secara menyeluruh menghambat lainnya yang terdapat dalam pupuk bokashi dapat meningkatkan keanekaragaman serta aktivitas mikroba dalam tanah sehingga mampu meningkatkan unsur hara dan menunjang pertumbuhan tanaman diantaranya tinggi tanaman. (Atikah, 2013).

\section{jumlah daun(helai)}

Hasil analisis ragam (Anova) menunjukkan bahwa perlakuan berbagai jenis pupuk bokashi tidak berpengaruh nyata terhadap jumlah daun (lampiran 10). Rataan jumlah daun dengan perlakuan pemberian berbagai macam pupuk bokashi dapat dilihat pada Tabel 2. 
vegetatif. Hal ini sebelumnya juga telah dijelaskan oleh Singgih (2011), yang menyatakan bahwa mudah terputusnya sistem perakaran muda sebagian besar pada media tanah yang keras dari selsel meristematik yang sedang giat-giatnya mengalami diferensiasi dan pertumbuhan pada sel-selnya.kondisi ini akan mempengaruhi suplai oksigen dalam tanah sehingga respirasi terhambat dan mengakibatkan bertumbuhan daunpun terhambat.

Rataan Jumlah Cabang Primer (buah) Hasil analisis ragam (Anova) menunjukkan bahwa perlakuan berbagai jenis pupuk bokashi tidak berpengaruh nyata terhadap jumlah cabang primer (lampiran 11). Rataan jumlah cabang primer dengan perlakuan pemberian berbagai macam pupuk bokashi dapat dilihat pada Tabel 3 .

Tabel 3. Rataan Jumlah Cabang Primer dengan Perlakuan Berbagai Jenis Pupuk Bokashi

\begin{tabular}{|l|l|}
\hline \multicolumn{1}{|c|}{ Perlakuan } & Jumlah Cabang Primer \\
& \\
\hline B0 $=$ Tanpa Perlakuan & 2.08 \\
B1 $=500$ g/polybag Bokashi Alang-alang & 2.17 \\
B2 $=500$ g/polybag Bokashi Eceng Gondok & 2.08 \\
B3 $=500 \mathrm{~g} /$ polibag bokashi serbuk Gergaji & 2.33 \\
B4 $=500 \mathrm{~g} /$ polibag Bokashi Pupuk Kandang Sapi & 2.58 \\
\hline KK $=17,60 \%$ & \\
\hline
\end{tabular}

Keterangan : Perlakuan tidak berpengaruh nyata terhadap rataan jumlah Cabang Primer $(\mathrm{P}>0,05)$.

Dari Tabel 3 terlihat bahwa perlakuan tidak berpengaruh nyata terhadap jumlah cabang primer, hal ini diduga cabang primer merupakan faktor genetik dari sifat tanaman terung, dimana setiap perlakuan menunjukan jumlah cabang primer yang hamper sama.

Marzuki, (2009) menyatakan bahwa pertumbuhan dan perkembangan tumbuhan terung usia vegetatif antara 30 hingga 110 hst sangat dipengaruhi oleh faktor dalam tumbuhan. Faktor dalam adalah semua faktor yang terdapat dalam tubuh tumbuhan antara lain faktor genetik pembawa sifat menurun yang terdapat di dalam setiap sel tumbuhan yang berfungsi mengatur sintesis enzim untuk mengendalikan proses kimia dalam sel. Hal ini diduga yang menyebabkan pertumbuhan dan perkembangan tanaman hingga mencapai 90 hst tidak menunjukan perbedaan yang signifikan antar perlakuan.
Selanjutnya Aji dan Susanto, (2013) menyatakan Potensi perkembang biakan tanaman terung sebagian besar ditentukan oleh gen dari tanaman. peningkatan pertumbuhan tanaman selama pertumbuhan fegetatif dipengaruhi karateristik sifat induk yang melekat sehingga faktor pemberian pupuk tidak menjadi pengaruh yang signifikan.

Adapun solusi untuk mendapatkan kwalitas tanaman yang memiliki daya tahan yang baik serta pertumbuhan yang ideal harus memperhatikan faktor genetik dan sifat dari induk yang unggul (Marzuki, 2008).

\section{Rataan jumlah buah (buah)}

Hasil analisis ragam (Anova) menunjukkan bahwa pemberian beberapa macam bokashi berpengaruh nyata terhadap jumlah buah (lampiran 12a). Rataan jumlah 
buah dengan pemberian perlakuan beberapa

macam bokashi dapat dilihat pada Tabel 4.

Tabel 4. Rataan Jumlah Buah dengan Perlakuan Pemberian Beberapa Macam Bokashi.

\begin{tabular}{|l|c|}
\hline \multicolumn{1}{|c|}{ Perlakuan } & Jumlah Buah \\
& \\
\hline B0 $=$ Tanpa Perlakuan & $6.14 \mathrm{~b}$ \\
B1 $=500 \mathrm{~g} /$ polybag Bokashi Alang-alang & $8.00 \mathrm{a}$ \\
B2 $\quad=500 \mathrm{~g} /$ polybag Bokashi Eceng Gondok & $8.83 \mathrm{a}$ \\
B3 $=500 \mathrm{~g} /$ polibag bokashi serbuk Gergaji & $9.00 \mathrm{a}$ \\
B4 $\quad=500 \mathrm{~g} /$ polibag Bokashi Pupuk Kandang Sapi & $9.50 \mathrm{a}$ \\
& \\
\hline KK $=13,48 \%$ & \\
\hline
\end{tabular}

Keterangan :Angka-angka yang diikuti oleh huruf kecil yang berbeda pada kolom yang sama menunjukkan berbeda nyata menurut DNMRT pada taraf $5 \%$.

Tabel 4. Menjelaskan perlakuan (B0) berbeda dengan perlakuan (B1). (B2), (B3) dan (B4). Perlakuan (B1) tidak berbeda dengan perlakuan (B2), (B3) dan (B4). Hal ini diduga pemberian berbagai macam pupuk bokashi setelah tanaman dewasa mampu diserap oleh tanaman secara optimum.

Pemanfaatan limbah organik yang berasal dari sisa tumbuhan dan kotoran hewan ternak yang telah dibuat menjadi bokashi dapat digunakan untuk memenuhi kebutuhan hara tanah. Pupuk bokashi dari kotoran sapi, mempunyai fungsi antara lain: menambah unsur hara tanaman, menambah kandungan humus dan bahan organik tanah, memperbaiki struktur tanah serta memperbaiki jasad renik tanah (Lokito, 2009).

Bokashi yang dibuat melalui proses pemanfaatan fermentasi E-M4 memiliki berbagai jenis bakteri sintetik, bakteri asam laktat, ragi, actinomycetes dan jamur yang dapat dimanfaatkan inokulan untuk meningkatkan keragaman mikrobia tanah (Ruhukai, 2011).

Bahan organik berfungsi memperbaiki porositas, kapasitas retensi air serta aerasi dan temperatur tanah. Bahan organik dengan
$\mathrm{C} / \mathrm{N}$ tinggi memberikan pengaruh yang lebih besar pada perubahan sifat-sifat tanah, baik sifat fisik, biologis, maupun sifat kimia tanah (Syam, 2003)

Suplai unsur hara yang cukup, menunjang pertumbuhan tanaman dan menghasilkan jumlah buah yang tinggi. Diketahui bahwa unsur hara $\mathrm{N}, \mathrm{P}$ dan $\mathrm{K}$ yang terkandung didalam bokashi merupakan unsur hara makro primer yang lebih banyak dibutuhkan tanaman dibandingkan unsur hara lainnya untuk membentuk bahan-bahan penting klorofil dan karbohidrat dalam proses fotosintesis, sehingga akan menghentikan proses pertumbuhan dan peningkatan jumlah buah. (Ruhukai, 2011).

\section{Rataan Hasil (Ton/ha).}

Hasil analisis ragam (Anova) menunjukkan bahwa pemberian beberapa macam bokashi berpengaruh nyata terhadap hasil ton/ha (lampiran 13a). Rataan hasil ton/ha dengan pemberian perlakuan beberapa macam bokashi dapat dilihat pada Tabel 5. 
Tabel 5. Rataan Hasil Ton/ha dengan

Macam Bokashi.

Perlakuan Pemberian Beberapa

\begin{tabular}{|l|c|}
\hline \multicolumn{1}{|c|}{ Perlakuan } & Hasil (Ton/ha). \\
\hline B0 $=$ Tanpa Perlakuan & $2.19 \mathrm{~b}$ \\
B1 $=500 \mathrm{~g} /$ polybag Bokashi Alang-alang & $2.86 \mathrm{a}$ \\
B2 $=500 \mathrm{~g} /$ polybag Bokashi Eceng Gondok & $3.15 \mathrm{a}$ \\
B3 $=500 \mathrm{~g} /$ polibag bokashi serbuk Gergaji & $3.19 \mathrm{a}$ \\
B $\quad=500 \mathrm{~g} /$ polibag Bokashi Pupuk Kandang Sapi & $3.39 \mathrm{a}$ \\
\hline KK $=13,52 \%$ & \\
\hline
\end{tabular}

Keterangan :Angka-angka yang diikuti oleh huruf kecil yang berbeda pada kolom yang sama menunjukkan berbeda nyata menurut DNMRT pada taraf 5\%.

Pada Tabel 5. Dapat dijelaskan bahwa perlakuan (B0) berbeda dengan perlakuan (B1), (B2), (B3) dan (B4). Selanjutnya dari perlakuan (B1) hingga (B4) tidak menunjukan perbedaan, namun secara keseluruhan berbagai macam jenis pupuk bokashi berbeda dengan perlakuan kontrol hal ini diduga bokashi dari hasil fermentasi EM4 memiliki kandungan zat perangsang tumbuh terhadap pertumbuhan serta mampu memperbaiki sistem perakaran, meningkatkan penyerapan hara, memperbaiki aktivitas enzim, sehingga mampu meningkatkan hasil tanaman terung.

Peningkatan produksi terung disebabkan pemberian bokashi berdampak memperbaiki sifat fisik, kimia dan biologi tanah. Perbaikan sifat fisik tanah karena bahan organik merupakan perekat butiran lepas atau bahan pemantap agregat (Irwan $d k k, 2005)$

Bahan organik membantu akar tanaman menembus tanah lebih dalam sehingga lebih mampu menyerap unsur hara dan air dalam jumlah banyak; memperbaiki rhizosfer yang dapat menjaga siklus hara, memperbaiki eksudasi oleh akar tanaman yang dapat meningkatkan degradasi bahan organik tanah dan mineralisasi $\mathrm{N}$ dan menghasilkan sumber energi dari sebagian besar organisme sehingga berkorelasi dalam meningkatkan produksi buah (Melati $d k k$ 2008)

Musnamar (2003) bahwa pemberian bahan organik jenis bokashi ke dalam tanah adalah hal yang sangat penting dilakukan untuk mempertahankan lahan pertanian agar tetap produktif, karena bahan organik yang telah terfermentasi dengan menggunakan media EM-4 selain dapat menambah unsur hara juga dapat meningkatkan kandungan bahan organik tanah yang penting dalam memperbaiki sifat fisik dan biologi tanah sehingga dapat meningkatkan hasil produksi buah.

Tanaman yang diberikan pupuk bokashi akan memiliki akumulasi biomassa bagian atas yang banyak dibandingkan dengan tanaman yang diberikan pupuk sintetis, dengan demikian dapat dijelaskan bahwa terdapat hubungan antara meningkatnya tinggi tanaman dengan produksi buah terung. Bahan organik jenis bokashi akan meningkatkan aktivitas biologis tanah dan juga meningkatkan ketersediaan air tanah. Dengan semakin tersedianya air tanah maka absorbsi dan transportasi unsur hara maupun air akan lebih baik, sehingga laju fotosintesis untuk dapat meningkatkan cadangan makanan bagi pertumbuhan tanaman lebih terjamin dan akhirnya produksi buah akan meningkat (Ruhukai, 2011). 


\section{KESIMPULAN}

1. Pemberian beberapa jenis pupuk bokashi terhadap pertumbuhan dan hasil tanaman terung berpengaruh nyata pada tinggi tanaman, jumlah buah per tanaman dan hasil ton/ha, akan tetapi tidak berpengaruh nyata terhadap jumlah daun dan cabang primer.

2. Perlakuan pupuk bokashi yang terbaik adalah pupuk bokashi kotoran sapi.

\section{DAFTAR PUSTAKA}

Aji, T.GG dan S. Susanto. 2013. Pengaruh Jumlah Cabang terhadap Pertumbuhan vegetatif dan generartif Rosela (Hibiscuz sabdariffa). Makalah Seminar Agronomi dan hortikultura. Fakultas Pertanian. IPB. Bogor

Atikah TA. 2013. Pertumbuhan dan hasil tanaman terung ungu varietas Yumi F1 dengan pemberian berbagai bahan organik dan lama inkubasi pada tanah berpasir. Anterior Jurnal 12(2):6-12.

Arianto, S. 2007. Bertanam Terung. Kanisisus. Yogyakarta

Badan Pusat Statistik Provinsi Jambi. 2015. Produksi Sayuran dan Buahbuahan Provinsi Jambi.

Darmawan 2008.Meningkatkan Produksi Tanaman dengan Kompos Alang-alang. Trubus, Jakarta.

Irwan, A.W., A. Wahyudin, R. Susilawati, T. Nurmala. 2005. Interaksi jarak tanam dan jenis pupuk bokashi terhadap komponen hasil dan kadar tepung sorgum
[Sorgum bicolor (Linn.) Moench.] pada Inseptisol di Jatinangor MH 2004. J. Kultivasi 4:128-136.

Imdad, H.P. dan A.A. Nawangsih. 2003. Budidaya Sayur-sayuran. Penebar Swadaya. Jakarta.

Djunaedy, A. 2009. Pengaruh Jenis dan Dosis Pupuk Bokashi Terhadap Pertumbuhan dan Hasil Kacang Panjang (Vigna sinensis L.). J. Agrovigo.

Kemas, A. H.2010. Dasar-dasar Ilmu Tanah. Raja Grafindo Persada. Jakarta.

Lokito, A. M. 2009. Bokashi: alternatif lain pupuk organik. Majalah Sema.

Marpaung, T 2010.Budidaya Tanaman Tropika. Penebar Swadaya. Jakarta.

Melati, M., A. Asiah, D. Rianawati. 2008. Aplikasi pupuk organik dan residunya untuk produksi kedelai panen muda. J. Agron. Indonesia.

Musnamar, E.I. 2003. Pupuk Organik Padat. Penebar Swadaya, Jakarta.

Nuryani S.H.U., Muhsin Haji dan Nasih Widya Y. 2010. Serapan Hara N, $\mathrm{P}, \quad \mathrm{K}$ Pada Tanaman Padi Dengan Pupuk Bolashi Campuran Serbuk Gergaki Pada Vertisol Sragen. Jurnal Ilmu Tanah dan Lingkungan.

Purwani JT. 2007. Pemanfaatan EM4 pada Dekomposisi Bahan Organik di Lahan Sawah.

Purwono dan Hartono, 2008. Analisis Pertumbuhan Tanaman Sayur sayuran. Agromedia. Jakarta. 
Rahmad.2000. Pengaruh Pemberian Pupuk Bokashi Kotoran Ayam terhadap Pertumbuhan Bibit Kelapa Sawit (Elaeis quineensis Jacq.) di Pembibitan Utama. Tesis Sarjana. Fakultas Pertanian Universitas Jambi, Jambi.

Rahmudin M. 2006. Pemanfaatan Limbah Serbuk Kayu Sebagai Media Tanam.Rhineka cipta. Jakarta.

Ruhukai NL. 2011. Pengaruh penggunaan EM4 yang dikulturkan pada bokashi dan pupuk anorganik terhadap produksi tanaman kacang tanah (Arachis hypogaea L.) di Kampung Wanggar Kabupaten Nabire. Jurnal Agroforestr.

Samadi. 2003. Budidaya Terung Hibrida. Kanisius. Yogyakarta.

Sirajuddin, M. dan S. A., Lasmini. 2010. Respon Pertumbuhan dan Hasil Tanaman Terung Pada Berbagai Waktu Pemberian Pupuk Nitrogen dan Ketebalan Mulsa Jerami. J. Agroland

Siswandi. 2006. Budidaya Tanaman Sayuran. Citra Aji Parama. Yogyakarta.

Singgih, S.2011 Sukses Bertanam Sayuran Secara Organik. Angkasa. Bandung. 2011

Soetasat dan Prasetya J. 2003. Budidaya Terung Hibrida. Kanisius.Yogyakarta.

Soplanit R. 2012. Pengaruh bokashi Kotoran Sapi pada berbagai tingkat kematangan dan pupuk Sp-36 terhadap serapan $\mathrm{P}$ dan pertumbuhan jagung (Zea mays L.) pada Tanah Ultisol.

Syam A. 2003. Efektivitas pupuk organik dan anorganik terhadap produktivitas padi di lahan sawah. Jurnal Agrivigor.

Syarif L. 2009. Kesuburan Tanah. Kerjasama USAID dengan University of Kentucky (WUAE Project).

Soverda N, Rinaldy, Susanti I.2008.Pengaruh Beberapa Jenis Bokashi Terhadap Pertumbuhan dan Hasil Tanaman Terung (Lycopersicon esculentum Mill.) di Polybag.

Subhan, F., Hamzah dan A. Wahab.2008. Aplikasi Bokashi Limbah Mebel Pada Tanaman Melon.Jurnal Agrisitem, Juni 2008.

Sumardi M, Kasim, Auzar S, Akhir N. 2007. Respon Padi pada Teknik Budidaya secara Aerobik dan Pemberian Bahan Organik Kompos Eceng Gondok. Jurnal Agrosia.

Sumbangan Pikiran Mendukung Kebijaksanaan Pemerintah dalam Upaya Khusus Gizi Sayur di Indonesia. Pusat Penelitian Sayur Indonesia. Kep.Riau.

Tola F, Hamzah, Dahlan, Kaharuddin.2007, Pengaruh penggunaan dosis pupuk bokashi kotoran sapi terhadap pertumbuhan dan 
produksi tanaman jagung. Jurnal Agrisistem.

Usman-Made. 2010. Respons Berbagai

Populasi Tanaman Terung Terhadap Pemberian Berbagai Jenis Pupuk Bokashi .Jurnal Agroteknologi. USU.Medan

Widarto. 2004. Cara Cepat Membuat Kompos Alang. Penebar Swadaya. Jakarta
Wididana, G.N., 2007. Bercocok Tanam Padi dengan Teknologi Kompos Eceng Gondok Vermentasi EM4. Departemen Kehutanan. Jakarta.

Widodo P. 2013. Telaah Kesuburan Tanah. Penerbit Angkasa. Bandung. 